\title{
河口干潟におけるへナタリの炭素埋没量に関する基礎的研究
}

\section{A Fundamental Study on Burial Carbon by Cerithidea cingulata in Tidal Flat of River Mouth}

\author{
大谷壮介 $^{1} \cdot$ 上月康則 ${ }^{2} \cdot$ 山中亮一 ${ }^{3}$ \\ Sosuke OTANI, Yasunori KOZUKI and Ryoichi YAMANAKA
}

\begin{abstract}
The carbon captured by living organisms in oceans is stored in the form of sediments from mangroves, salt marshes and seagrasses. We evaluated the blue carbon sinks by gastropod Cerithidea cingulata in river mouth tidal flat. We determined oxygen consumption of $C$. cingulata in the air and water conditions. Oxygen consumption grew with increasing temperature and shell length in both conditions. Approximately $80 \%$ of the carbon biomass was an inorganic carbon from shell origin. We calculated that the amount of carbon source as respiration and dead was 26 $\mathrm{kgC} /$ year, sink as production, shell formed, shell buried was $40 \mathrm{kgC} /$ year in this muddy tidal flat. These results indicated that $C$. cingulata plays a role for contribution to sink the blue carbon.
\end{abstract}

\section{1. 緒論}

2009年，国連環境計画（UNEP）により，地球上の生 物が固定化する炭素の $55 \%$ がブルーカーボン由来である ことが報告された（Nellemannら，2009)。その中でも海 洋生態系によって固定，埋没される炭素（ブルーカーボ ン）において，底生生物の役割が大きいと言われている が，干潟では従来から有機物の生産・分解機能の研究が 中心であり，炭素の埋没する機能やそのメカニズムにつ いては未だ明らかになっていない。そこで本研究では, 河口干潟において，腹足類の一種であるへナタリ Cerithidea cingulataに着目し，干潟に扔ける腹足類の炭素埋没量を 推定し，底生生物による炭素埋没量を明らかにすること を目的とした。

\section{2. 研究方法}

\section{(1) 現存量調查}

調査は勝浦川河口干潟において 2004 年 1月～2009年 9 月まで行った（図-1）。ヘナタリの現存量調査は泥質干潟 (約 $\left.5000 \mathrm{~m}^{2}\right)$ の 13 地点に扔いて $50 \times 50 \mathrm{~cm}$ の方形区を用 いて，まず方形区内の表層に生息していたへナタリを採 集し，深さ約 $2 \mathrm{~cm}$ までの堆積物を $2 \mathrm{~mm}$ ふるいでふるい， ふるい上に残ったへナタリを採集した。採集したへナタ リは実験室に持ち帰り，殸高の測定を行い，個体数を記 録した後，元の場所へ返した。ヘナタリの現存量調查結 果より，コホート解析によって年齢別個体群に分割し， 生産量は平均生息密度に個体の平均増重量を乗じたもの
1 正会員 博 (工) 京都大学大学院工学研究科附属流域圈総合 環境質研究センター研究員
2 正会員 博(工) 徳島大学大学院ソシオテクノサイエンス
研究部教授
3 正会員＼cjkstart博(工) 徳島大学大学院ソシオテクノサイエンス 研究部講師

として, 死亡量は生息密度の減少量に平均重量を乗じた ものとしてそれぞれ以下の式より算出した。

$$
\begin{aligned}
& \mathrm{P}=\sum\left(\mathrm{W}_{\mathrm{t}+1}-\mathrm{W}_{\mathrm{t}}\right) \times\left(\mathrm{N}_{\mathrm{t}+1}+\mathrm{N}_{\mathrm{t}}\right) / 2 \\
& \mathrm{M}=\sum\left(\mathrm{W}_{\mathrm{t}+1}+\mathrm{W}_{\mathrm{t}}\right) \times\left(\mathrm{N}_{\mathrm{t}}-\mathrm{N}_{\mathrm{t}+1}\right) / 2
\end{aligned}
$$

ここで, $\mathrm{P}$ : 生産量, $\mathrm{M}$ ：死亡量, $\mathrm{Wt}$ ：時間 $\mathrm{t}$ における

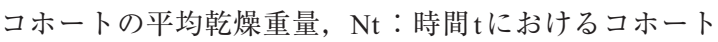
の平均個体群密度である。本研究では大谷ら（2011）に よって計算されたへナタリの成長曲線および個体群密度 から表-1に示したへナタリの殼高と各項目の関係を用い て生産量, 死亡量を算出した。なお，貝殼の無機炭素に ついては，乾燥させた貝殼を $600^{\circ} \mathrm{C}$ の電気炉で繰り返し 灰化を行った後，元素分析装置（Thermo Finigan社製 FLASH EA1112）にて炭素含有量の測定を行った。

\section{(2) 呼吸量}

ヘナタリの呼吸量を定量化するために，干潟が干出し ている場合と冠水している場合を想定した 2 通りの実験 を行った，干潟が干出している場合を想定した実験では， 酸素消費量測定装置 $\left(\mathrm{O}_{2}\right.$ UP TESTER，TAITEC社製）を 用いてへナタリの陸上での酸素消費速度の測定を行っ た．本装置は容器内に水酸化ナトリウムを入れることに よってへナタリが排出した二酸化炭素は吸収され，酸素

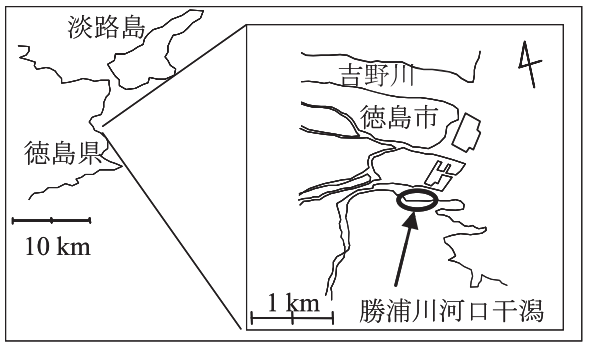

図-1 調查地域 
表-1 ヘナタリの凯高と各項目の関傒（Y：各項目， $\mathrm{X}$ ：へナ タリの款高 $(\mathrm{mm}))$

\begin{tabular}{lcc}
\hline \multicolumn{1}{c}{ 項目 } & 回帰式 & 決定係数: $\mathrm{R}^{2}$ \\
\hline 身湿重 $(\mathrm{g}$ wet $)$ & $\mathrm{Y}=1.50 \times 10^{-6} \mathrm{X}^{3.76}$ & 0.92 \\
身乾重量 $(\mathrm{g}$ dry $)$ & $\mathrm{Y}=1.72 \times 10^{-6} \mathrm{X}^{3.28}$ & 0.93 \\
身全有機炭素量 $(\mathrm{mgC})$ & $\mathrm{Y}=1.51 \times 10^{-3} \mathrm{X}^{3.05}$ & 0.93 \\
身全窒素量 $(\mathrm{mgN})$ & $\mathrm{Y}=1.72 \times 10^{-3} \mathrm{X}^{2.50}$ & 0.76 \\
款乾重量 $(\mathrm{gdry})$ & $\mathrm{Y}=7.19 \times 10^{-5} \mathrm{X}^{2.93}$ & 0.92 \\
凯無機炭素量 $(\mathrm{mgC})$ & $\mathrm{Y}=2.00 \times 10^{-3} \mathrm{X}^{3.35}$ & 0.91 \\
\hline
\end{tabular}

消費速度のみを測定している，本研究では同一個体を用 いて，同一の条件下で水酸化ナトリウムを用いた系拉よ び水酸化ナトリウムを用いない系にて実験を行った。こ れによって，水酸化ナトリウムを用いた系では酸素消費 速度が測定され，水酸化ナトリウムを用いない系では二 酸化炭素が吸収されないことから（酸素消費速度一二酸 化炭素排出速度）が測定される。これら2つの值から二 酸化炭素排出速度を推定した。実験は， 1 年を 4 シーズン に分け，温度をそれぞれ $20{ }^{\circ} \mathrm{C}$ (春), $30^{\circ} \mathrm{C}$ (夏), $20^{\circ} \mathrm{C}$ (秋)， $10^{\circ} \mathrm{C}$ (冬) に設定し，測定を行った。な拉，実験 に供した個体はそれぞれの季節において干潟で採取した あと，実験室にて 1 週間程度の馴致を行った後に，24時 間の絶食状態に扮き，糞の排泄を行い，測定温度と同様 の温度条件下で害施した。

一方，干潟が冠水している場合を想定した実験では， ヘナタリの水中での酸素消費速度を測定した。干出を想 定した実験と同様にへナタリを採取したのち，実験室に て24時間の絶食状態におき，糞の排泄を行った後，海水 で満たした $100 \mathrm{ml}$ のフラン瓶にへナタリを投入し，ス卜 レス解消のため 2 時間放置した。 その後, 酸素飽和させ た状態のオートクレーブ滅菌後のろ過海水と交換し，溶 存酸素濃度の変化から酸素消費速度を測定した（東亜 DKK製 DO21-P)。実験条件は水温を $30 ， 20 ， 10^{\circ} \mathrm{C}$ に設 定し，測定は3時間とした。

\section{3. 結果}

\section{（1）酸素消費速度}

\section{a) 干出中の酸素消費速度}

それぞれの季節におけるへナタリの酸素消費速度と款 高の関係を図-2に示す。ヘナタリの酸素消費速度は測定 温度が上昇するほど速くなる傾向が確認された. $30^{\circ} \mathrm{C}$ お よび $10{ }^{\circ} \mathrm{C}$ の酸素消費速度は，それぞれ 24.4 㧍よび $0.5 \mu \mathrm{LO}_{2} / \mathrm{h}$ であり, $30^{\circ} \mathrm{C} の$ 方が 49 倍速くなった（表-2). これは，温度が上昇することに伴いへナタリの呼吸活性 が高くなったためである。へナタリの酸素消費速度と殼 高の回帰式を示した表-3より，すべての季節において統 計的に有意な回帰式が得られた。

\section{b）冠水中の酸素消費速度}

干潟が冠水している水中でのへナタリの酸素消費速度

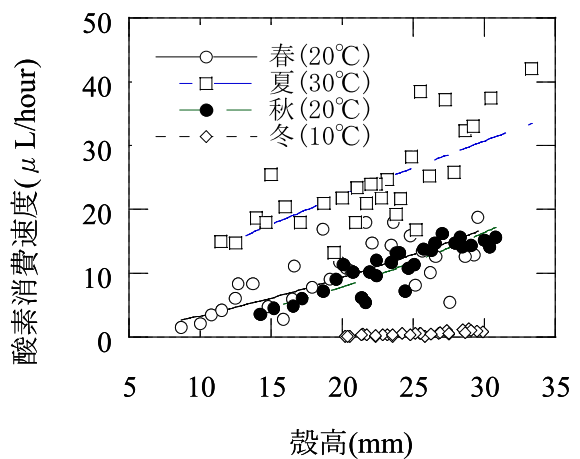

図-2干出中のへナタリの酸素消費速度

表-2 ヘナタリの酸素消費速度の比較

\begin{tabular}{ccc}
\hline 温度 $\left({ }^{\circ} \mathrm{C}\right)$ & \multicolumn{2}{c}{$\begin{array}{c}\text { 酸素消費速度 }\left(\mu \mathrm{LO}_{2} / \mathrm{h}\right) \\
\text { 干出 }\end{array}$} \\
\hline 10 & 0.5 & 冠水 \\
\hline 20 & 10.0 & 5.4 \\
30 & 24.4 & 12.4 \\
\end{tabular}

表-3 干出中のヘナタリの款高と酸素消費速度の関係 $\mathrm{Y}$ ：酸素 消費速度 $\left(\mu \mathrm{LO}_{2} / \mathrm{h}\right), \mathrm{X}:$ ヘナタリの殸高 $(\mathrm{mm})$

\begin{tabular}{ccc}
\hline 季節 & 回帰式 & 決定係数: $\mathrm{R}^{2}$ \\
\hline 春 & $\mathrm{Y}=0.111 \mathrm{X}^{1.477}$ & 0.45 \\
夏 & $\mathrm{Y}=2.016 \mathrm{X}^{0.801}$ & 0.55 \\
秋 & $\mathrm{Y}=0.034 \mathrm{X}^{1.820}$ & 0.77 \\
冬 & $\mathrm{Y}=5.814 \times 10^{-8} \mathrm{X}^{4.903}$ & 0.67 \\
\hline
\end{tabular}

と殼高の関係を図-3に示し，その回帰式と決定係数を表-4 に示す. 干出時と同様に，ヘナタリの酸素消費速度は測 定温度が上昇するほど速くなる傾向が確認された. $30^{\circ} \mathrm{C}$ および $10{ }^{\circ} \mathrm{C}$ の平均の 1 個体当たりの酸素消費速度は，そ れぞれ 24.8 および $5.4 \mu \mathrm{LO}_{2} / \mathrm{h}$ であり， $30^{\circ} \mathrm{C}$ の方が 4.6 倍速 くなった（表-2）。また，干出時と冠水時のへナタリの酸 素消費速度を比べると， $10{ }^{\circ} \mathrm{C}$ を除いてほぼ同じような值 を示した。

\section{c）個体群の炭素排出量}

現存量結果より，コホート解析によって年齢別個体群 に分割し，個体群の成長を追ったへナタリの成長曲線抒 よび個体群密度の結果を用いて（大谷ら，2011），本干 潟におけるへナタリのコホート単位での呼吸による炭素 排出速度の推定を行った。へナタリの個体群の炭素排出 速度を推定した期間は毎月の現存量調查の結果から得ら れたコホート毎に，それぞれの調査月の干出および冠水 時間を考慮して算出した。ここでは，春（3～5月），夏 (6〜8月), 秋 $(9 \sim 11$ 月), 冬 $(12 \sim 2$ 月) の 4 つの季節 に区分した。なお，酸素消費速度から二酸化炭素排出速 度へ換算を行うために干出時を想定した実験より得られ た呼吸商を用いており，呼吸商は $0.68 〜 0.72$ の範囲で表 され，季節間での差はほとんどなかったことを確認して 


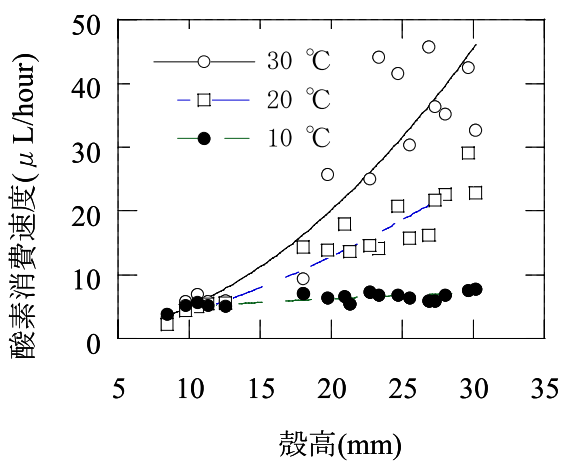

図-3 冠水中のヘナタリの酸素消費速度

表-4 冠水中のヘナタリの殼高と酸素消費速度の関係 $\mathrm{Y}$ : 酸素 消費速度 $\left(\mu \mathrm{LO}_{2} / \mathrm{h}\right), \mathrm{X}$ : ヘナタリの凯高 $(\mathrm{mm})$

\begin{tabular}{ccc}
\hline 季節 & 回㷌式 & 決定係数: $\mathrm{R}^{2}$ \\
\hline 春 & $\mathrm{Y}=0.0477 \mathrm{X}^{2.017}$ & 0.80 \\
夏 & $\mathrm{Y}=0.0908 \mathrm{X}^{1.653}$ & 0.89 \\
秋 & $\mathrm{Y}=0.0477 \mathrm{X}^{2.017}$ & 0.80 \\
冬 & $\mathrm{Y}=2.254 \mathrm{X}^{0.341}$ & 0.62 \\
\hline
\end{tabular}

表-5 ヘナタリの呼吸商

\begin{tabular}{cccc}
\hline 季節 & 温度 $\left({ }^{\circ} \mathrm{C}\right)$ & 呼吸商 & 決定係数: $\mathrm{R}^{2}$ \\
\hline 春 & 20 & 0.69 & 0.85 \\
夏 & 30 & 0.71 & 0.85 \\
秋 & 20 & 0.72 & 0.83 \\
冬 & 10 & 0.68 & 0.83 \\
\hline
\end{tabular}

\section{いる(表-5).}

ヘナタリ個体群の呼吸による炭素排出速度の経月変化 を図-4に示す。炭素排出速度は，春期から夏期に徐々に 増加し，夏期に最も高くなり，秋期から冬期かけて減少 する傾向が認められ，季節変化の大きいことが確認でき る。炭素排出速度は, 2005 年 2 月に $0.026 \mathrm{gC} / \mathrm{m}^{2} / \mathrm{month}$ と最 も低く，2008年 10 月に $1.23 \mathrm{gC} / \mathrm{m}^{2} / \mathrm{month}$ と最も高かった。

\section{(2) 炭素収支}

大谷ら（2011）により得られたへナタリの各コホート
の成長曲線および表-1の結果を用いて現存量, 生産量, 死亡量の推定をそれぞれ行った。ヘナタリの現存量は $7.85 \pm 0.52 （ 2.0 \sim 18.9 ） \mathrm{gC} / \mathrm{m}^{2}$ と冬期に低い值を示した のに対して，春期から秋期に高い值を示し（図-5)，その 内訳として約 8 割が無機炭素によるものであった。

ヘナタリのよる炭素固定量および排出量を表-6に示 す.ヘナタリの有機炭素の生産量は $1.05 \pm 0.22 \mathrm{gC} / \mathrm{m}^{2} /$ year, 無機炭素の生産量は $3.81 \pm 0.84 \mathrm{gC} / \mathrm{m}^{2} /$ yearであった。当 泥質干潟ではヤマトオサガニの調査も同時に行われてお り，ヤマトオサガニの年間生産量は $5.58 \pm 0.51 \mathrm{gC} / \mathrm{m}^{2} /$ year （大谷ら，2006）と, ヘナタリの有機炭素の生産量はヤ マトオサガニの生産量の $1 / 5$ 以下であるが，貝殼形成に よる無機炭素の生産量も考慮することで, 有機炭素の生 産量と合わせて $4.86 \pm 1.01 \mathrm{gC} / \mathrm{m}^{2} /$ yearの固定量が見積も られる。

ヘナタリが死亡することによって，有機炭素は $0.85 \pm$ $0.18 \mathrm{gC} / \mathrm{m}^{2} /$ yearが排出されるが，無機炭素である貝殼は固 定される．この固定される貝殸の無機炭素は2006年にマ イナスを示していたが，他の年を比べると貝殼形成によ って生産された無機炭素と同等かそれ以上の值を示して おり，2006年の值を除いたへナタリの死亡による貝殼の 固定量は $3.23 \pm 0.31 \mathrm{gC} / \mathrm{m}^{2} /$ yearであった（表-6）。また， 排出量である呼吸量は $4.26 \pm 0.49 \mathrm{gC} / \mathrm{m}^{2} /$ year と死亡量に 比べて約 5 倍であった。

以上のことより，対象とした泥質干潟の面積が $5000 \mathrm{~m}^{2}$ であることから本干潟域での炭素収支を算出すると，排 出量は $26 \mathrm{kgC} /$ year, 固定量は $40 \mathrm{kgC} /$ year と固定量の方が 大きくなっていた.

\section{4. 考察}

干潟における炭素動態は，有機物の生産・分解に関す る研究が中心であり，固定量の中でも埋没量に着目した 研究はマングローブにおける事例がある。 マングローブ ではリターは埋没し（赤松ら，2002），これらはカニ類

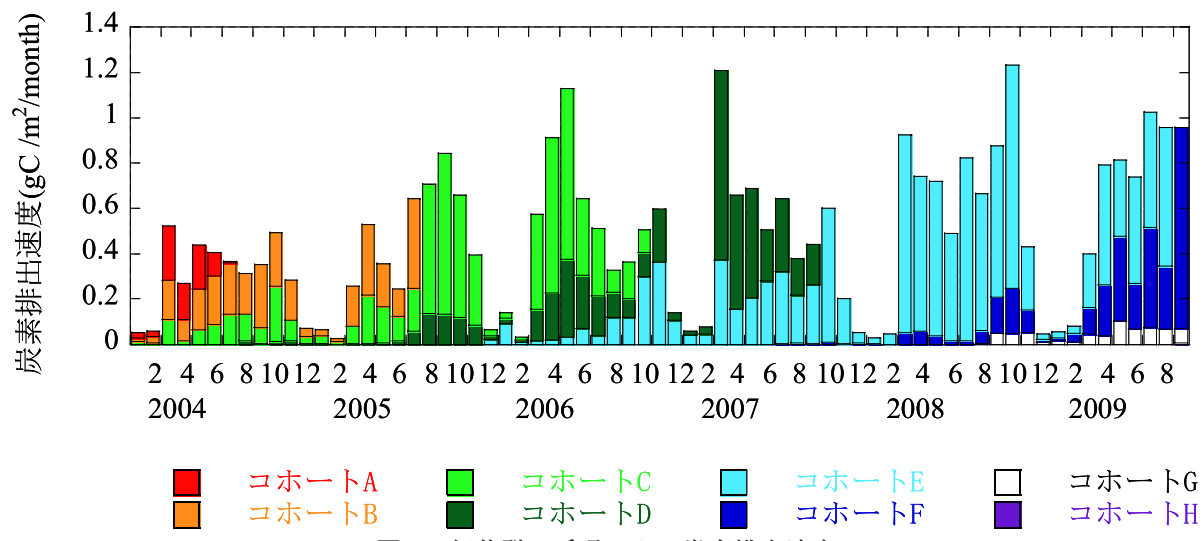

図-4 個体群の呼吸による炭素排出速度 


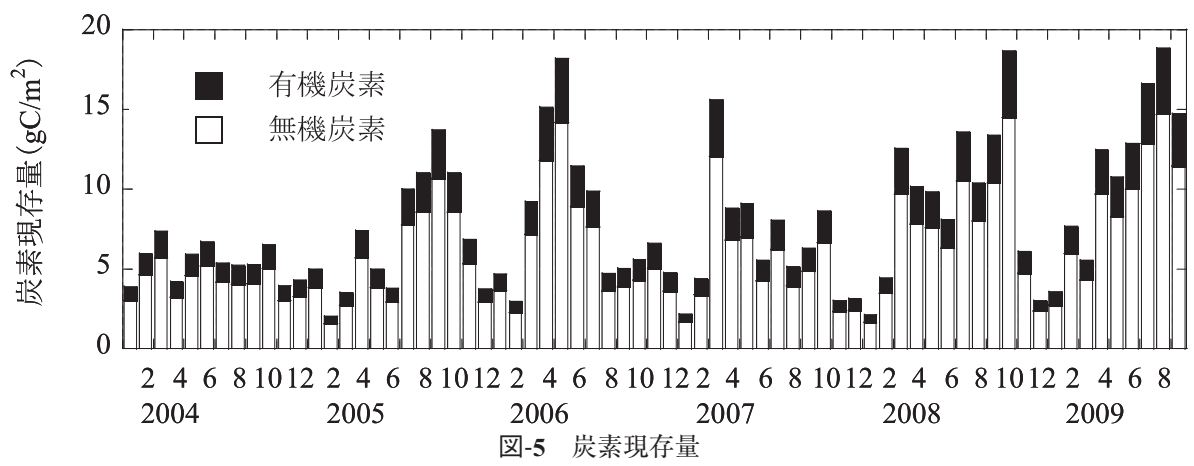

表-6 炭素固定量および排出量

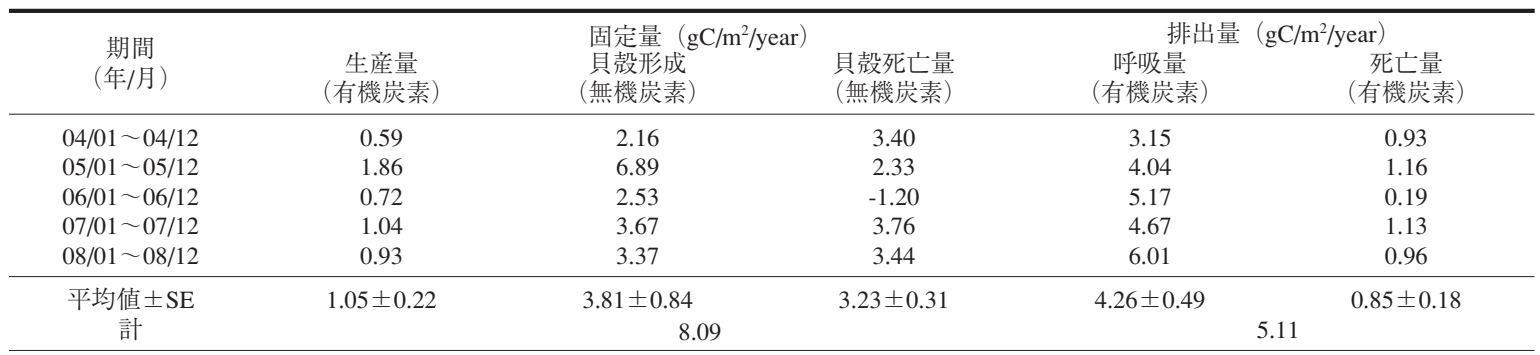

に利用される形で有機炭素の食物連鎖が形成されてお り，残った物はデトリタスとなって分解・埋没する過程 で，一部はデトリタス食者に利用されている。 また，底 生生物は高次捕食者による被食や死亡個体はアラムシロ ガイ等の腐肉食者, バクテリアにも利用される炭素フロ 一がある，一方で，河口干潟では，腹足類が多く生息し ており，その貝殼はヤドカリ類に利用されるものの，長 期間にそのままの形で埋没していく。これらは二次的に 利用されることはなく, 分解・系外への除去もないため, その埋没量は大きいと考えられる。

ヘナタリの無機炭素生産量/有機炭素生産量比は3.59 0.04 となり, 中村ら (2003b) からマガキやサルボウ等の 主要貝類の 8 種の無機炭素/有機炭素比は 1.6 ～ 3.5 と算出 され，アサリと同程度で他の貝類と比べると高い值を示 した。つまり，へナタリは他の貝類と比べると有機炭素 生産量に対して無機炭素生産量が高く, 貝凯形成による 無機炭素が大きく生産されていることが示される．懸濁 物除去機能の高い二枚貝の中でもアサリやカキ等の水産 有用種は漁獲により干潟から系外へ運び出されるが，へ ナタリは水産対象種でもなく，また系外除去するような 捕食者もいないことから, 堆積物上を葡萄する腹足類は 干潟周辺に埋没しやすい生物と思われる.

ところで, 森林の炭素固定量に着目してみると温帯林 の純一次生産量は $0.65 \mathrm{kgC} / \mathrm{m}^{2} /$ year と報告されている（大 谷，2001). 本対象干潟における底生微細藻類による一 次生産量は $0.32 \mathrm{kgC} / \mathrm{m}^{2} /$ year と他の干潟と比べると低いが
（大谷ら，2006）, 干潟域ではこのほかにも植物プランク トンによる一次生産も行われている。 また, 地下茥や草 体, 海中への流出・移送等を考慮した藻場による炭素固 定量は，アマモ場で $0.10 \mathrm{kgC} / \mathrm{m}^{2} /$ year，アラメ・カジメ場 で $1.67 \mathrm{kgC} / \mathrm{m}^{2} /$ year, コンブ場およびガラモ場でそれぞれ $0.13 \mathrm{kgC} / \mathrm{m}^{2} /$ yearおよび $0.60 \mathrm{kgC} / \mathrm{m}^{2} /$ year と試算されている (伊藤ら、2009)。これらと比較すると, ヘナタリの炭素 固定量は $8.09 \mathrm{gC} / \mathrm{m}^{2} /$ year と森林の炭素固定量の約 $1 / 80$ 程 度，アマモ場の約 $1 / 12$ 程度であった。

また，海水中の二酸化炭素量へ直接的に影響する代謝 機能として呼吸の他に石灰化に伴う分圧の上昇を検討す る必要がある。石灰化は以下の式（3）で表され, 石灰 化に伴う二酸化炭素の固定はサンゴ礁については詳細に 調べられており, 室内実験（仲座ら，1994）, 現地実験 (茅根，1993）によりサンゴは二酸化炭素を固定してい ることが示されている.

$$
\mathrm{Ca}^{2+}+2 \mathrm{HCO}_{3}^{-} \rightarrow \mathrm{CaCO}_{3}+\mathrm{CO}_{2}+\mathrm{H}_{2} \mathrm{O}
$$

中村ら (2002, 2003a）はウバガイやカキの石灰化に 伴う二酸化炭素の分圧を検討しており，同様の方法を用 いてへナタリにも適用するとサンゴ礁の場合には $1 \mathrm{~mol} の$ 石灰化に伴って $0.6 \mathrm{~mol}$ の二酸化炭素を排出することか ら, 石灰化に伴う二酸化炭素排出量は $2.29 \mathrm{kgC} / \mathrm{m}^{2} /$ year と 推定された。これを表-6に示したへナタリの排出量に加 算すると, 排出量は $7.40 \mathrm{kgC} / \mathrm{m}^{2} /$ year となり, 固定量と比 較することでへナタリは $0.69 \mathrm{kgC} / \mathrm{m}^{2} /$ yearを炭素固定して いると試算できる。なお，式（3）で表される石灰化の 
過程は水中で起こっているため, 干潟の干出時間を考慮 すると,さらに二酸化炭素排出量は低くなると見積もら れる。したがって，腹足類であるへナタリはウバガイや カキ等の二枚貝とは異なり，干満を繰り返す干潟域では 石灰化に伴う二酸化炭素排出の過程に特徵がある。以上 のことから，へナタリの炭素固定の特徵は，固定量は少 ないが，長期間，土壤中に貯蓄するという，炭素の埋没 時間に大きな特徵があると言える。

一般に，ヘナタリはワンド形式の泥質干潟の高い地盤 環境を好む（大谷ら，2011）。このような環境は，一次 生産活性が高く，また付着藻類を摂䬣するための干出時 間も長い，そのため藻類からへナタリへの転換効率も高 いことが推察される。またワンド環境は波浪や洪水等の 擋乱規模や頻度が小さいことから，場も安定しており， ヘナタリの生産に伴う炭素の埋没も安定して行われると 考えられる。このように，本研究では炭素埋没といった 観点からワンド干潟の新たな環境価值について論じるこ とができた。

\section{5. 結論}

1）へナタリの酸素消費速度を干出，冠水を想定した実 験系にて計測した結果，温度，殼高が増加するに伴っ て酸素消費速度も大きくなることを示した．また，干 出時と冠水時のへナタリの酸素消費速度を比べると, $10{ }^{\circ} \mathrm{C}$ を除いてほぼ同じような值を示した。さらに，毎 月の現存量調查結果を用いて，ヘナタリ個体群の呼吸 による炭素排出速度を算出したところ, 炭素排出速度 は，春期から夏期に徐々に増加し，夏期に最も高くな り, 秋期から冬期かけて減少する傾向が認められ，季 節変化の大きいことが推定された。

2）へナタリの炭素現存量を有機，無機炭素別に算出し た結果，約 8 割が貝款由来の無機炭素によるものであ った、へナタリの無機炭素と有機炭素の生産量比は他 の主要貝類と比較した結果，アサリと同程度で他の貝 類と比べると高い值を示した。 よって，ヘナタリは有 機炭素生産量に対して無機炭素生産量が高く, 貝殸形 成による無機炭素が大きく生産されていることがわか った.

3） 5 年間のヘナタリの炭素収支を算出すると，ヘナタリ
が死亡することにより，無機炭素である貝款は干潟に 固定され，有機・無機炭素生産量を足し合わせると $8.09 \mathrm{gC} / \mathrm{m}^{2} /$ yearが干潟に固定されていることがわかっ た。また死亡しても，貝款として $40 \mathrm{kgC} /$ yearの炭素を 干潟内に埋没させる機能がへナタリにはあることがわ かった.

謝辞 :ヘナタリの貝殸の無機炭素量を測定するにあたり 有益なご助言をいただいた磯野良介氏（財団法人海洋生 物環境研究所）に謝意を表します。また，本研究を実施 するにあたり, 実験・調査に協力頂いた徳島大学研究室 学生一同に感謝いたします。

\section{参 考 文 献}

赤松良久・池田駿介・中嶋洋平・戸田祐嗣（2002）：現地観測 に基づくマングローブ水域における有機物・栄養塩輸送 に関する研究，土木学会論文集，698，pp.69-80.

伊藤 靖 - 中野喜央・松下 訓 - 三上信雄・横山 純 - 桐原 慎二・能登谷正浩（2009）：藻場による炭素固定量の試算, 水産工学, 46, pp.135-146.

大谷壮介 - 上月康則 - 仲井薰史 - 石山 哲 - 村上仁士 （2006）：干潟の底生微細藻類量の季節変動に及ぼすヤマ トオサガニの掑䭒圧の影響に関する考察，海岸工学論文 集, 53, pp.1056-1060.

大谷壮介・上月康則・山中亮一 (2011)：徳島県勝浦川河口干 潟に抒けるへナタリの分布特性と個体群動態，土木学会 論文集 B3-67 (海洋開発), 印刷中.

大谷義和（2001）：二酸化炭素フラックス，森林科学，33, pp.10-17.

茅根 創（1993）：サンゴ礁による二酸化炭素の固定，地質二 ユース, 465, pp.19-25.

仲座栄三・津嘉山正光・清家邦宏（1994）：サンゴの光合成と 二酸化炭素の固定に関する研究, 海岸工学論文集, 41 , pp. 1026-1030.

中村義治 - 奥出 壮 - 寺澤知彦 - 関根幹男 - 三村信男 (2003a)： $\mathrm{CO}_{2}$ 固定量評価に係わる貝類代謝モデルの開発養殖カキ-, 海岸工学論文集, 50, pp.1166-1170.

中村義治・金綱紀久恵・磯野良介・三村信男（2002）：貝類の 生物機能と水域環境への影響に関する全国評価，海岸工 学論文集, 49, pp.1371-1375.

中村義治・金綱紀久恵・磯野良介・三村信男（2003b）：我が 国に扔ける主要貝類の生物量と生物機能の分布特性, 海 岸工学論文集, 50, pp.1296-1300,

Nellemann, C., Corcoran, E., Duarte, C.M., Valdes, L., DeYoung, C., Fonseca, L., Grimsditch, G. (Ed.) (2009): Blue carbon: The role of healthy oceans in binding carbon. A Rapid Response Assessment. United Nations Environment Programme, GRIDArendal.pp.1-78. 